This item was submitted to Loughborough's Research Repository by the author.

Items in Figshare are protected by copyright, with all rights reserved, unless otherwise indicated.

\title{
It's not all about the baby: Post-partum weight loss as a motivator for breastfeeding initiation and continuation
}

PLEASE CITE THE PUBLISHED VERSION

https://doi.org/10.1016/j.appet.2016.08.095

PUBLISHER

(C) Elsevier

VERSION

AM (Accepted Manuscript)

\section{PUBLISHER STATEMENT}

This work is made available according to the conditions of the Creative Commons Attribution-NonCommercialNoDerivatives 4.0 International (CC BY-NC-ND 4.0) licence. Full details of this licence are available at: https://creativecommons.org/licenses/by-nc-nd/4.0/

\section{LICENCE}

CC BY-NC-ND 4.0

\section{REPOSITORY RECORD}

Witcomb, Gemma, Sophie C. Schalla, and Emma Haycraft. 2019. "It's Not All About the Baby: Post-partum Weight Loss as a Motivator for Breastfeeding Initiation and Continuation”. figshare. https://hdl.handle.net/2134/28272. 


\title{
It's not all about the baby: Post-partum weight loss as a motivator for breastfeeding initiation and continuation
}

\author{
Gemma L Witcomb*, Sophie C Schalla, Emma Haycraft
}

School of Sport, Exercise \& Health Sciences, Loughborough University, UK

* G.L.Wltcomb@lboro.ac.uk, +44(0)1509223084.

UK breastfeeding rates are very low. Efforts to promote breastfeeding typically include focusing on the known health benefits for mother and child. However, these are rarely identifiable to parents (e.g., increased immunity) and may be temporally delayed. Gaining more immediate, tangible benefits can be an effective motivator of behaviour. Body-related changes resulting from breastfeeding could be one such example of an immediate benefit. This study aimed to explore breastfeeding mothers' reports of body-related changes as benefits of breastfeeding. Mothers $(\mathrm{N}=182)$ who currently, or had recently, breastfed an infant completed a survey detailing their infant feeding choices and the perceived benefits of breastfeeding on their bodies. It was found that half of the mothers indicated that they felt breastfeeding had a positive effect on their body. Benefits were grouped into five themes: 1. Returning to pre-pregnancy body shape; 2. Health benefits; 3. Physical benefits; 4. Eating benefits; 5. Psychological benefits. These themes highlight the numerous body-related benefits that mothers identified as resulting from breastfeeding and suggest that immediate, personal, and appearance-related gains of breastfeeding are highly valued. While interventions to promote breastfeeding tend to focus on the health and bonding benefits, these findings indicate that placing increased emphasise on the physical and psychological benefits may be valuable in encouraging breastfeeding initiation and continuation. Such an approach may be particularly effective for groups whose emphasis on body image may be greater, such as young mothers, where breastfeeding rates are low. 